УДК 327

DOI 10.18413/2687-0967-2020-47-2-416-426

\title{
ЭВОЛЮЦИЯ ПРИОРИТЕТОВ АРКТИЧЕСКОЙ ПОЛИТИКИ СТРАН СЕВЕРНОЙ ЕВРОПЫ (НА ОСНОВЕ КОНТЕНТ-АНАЛИЗА ДОКТРИНАЛЬНЫХ ДОКУМЕНТОВ)
}

\section{EVOLUTION OF ARCTIC POLICY PRIORITIES OF THE NORDIC COUNTRIES (BASED ON CONTENT ANALYSIS OF DOCTRINES)}

\author{
С.А. Бокерия, Е.А. Кернер, Д.А. Кузнецова \\ S.A. Bokeriya, E.A. Kerner, D.A. Kuznetsova \\ Российский университет дружбы народов, \\ Россия, 117198, г. Москва, Ул. Миклухо-Маклая, д. 6 \\ RUDN University, \\ 6 Mikluho-Maklaja, Moscow, 117198, Russia
}

\author{
E-mail: bokeria_sa@rudn.university, 1032193526@pfur.ru,1032193937@pfur.ru
}

\begin{abstract}
Аннотация
Арктика представляет интерес для многих региональных и нерегиональных акторов. Среди региональных акторов можно выделить группу североевропейских стран, которые заинтересованы в развитии своей политики в арктическом регионе. В 2000-х гг. пять циркумполярных государств - Норвегия, Дания, Финляндия, Швеция и Исландия - разработали собственные арктические стратегии, в которых они обозначили основные приоритеты и направления внешней и внутренней политики по отношению к Арктике. В данной работе содержание арктических доктринальных документов данной группы стран было рассмотрено с помощью контент-анализа. Таким образом, текстовое содержание документов было преобразовано в количественный формат, что позволило более наглядно продемонстрировать отличия приоритетов арктической внешней политики циркумполярных стран.
\end{abstract}

\begin{abstract}
The Arctic is of special interest for many regional and non-regional actors because there is great amount of natural resources and prospective sea routes in this region. Among regional actors there is a group of northern European countries that are interested in the development of their policy in the Arctic region. In 2000s arctic strategies were developed by 5 circumpolar countries of Northern Europe - Norway, Denmark, Finland, Sweden and Iceland. In these documents this group of countries highlighted the main priorities and directions of their foreign and domestic policy in the Arctic. In this article arctic strategies of circumpolar countries were examined with the help of content analysis. To identify the priorities keywords corresponding to the main directions of arctic policy of circumpolar countries were highlighted. Then the frequency of these keywords in arctic documents was analyzed. Thus text content was converted to quantitative data. Due to this differences between priorities of different countries' arctic policy was shown more clearly.
\end{abstract}

Ключевые слова: Арктика, государства Северной Европы, арктические стратегии, контентанализ, приоритеты, направления политики.

Keywords: the Arctic, the Nordic states, arctic strategies, content analysis, priorities, policy directions.

В группу арктических стран входят восемь государств, которые находятся в разных географических регионах: в Евразии - Россия, в Северной Америке - США и Канада, в Северной Европе - Дания, Норвегия, Исландия, Швеция и Финляндия. Говоря о странах Северной Европы, стоит отметить, что они обладают разными потенциалами в Арктике. 
Так, Дания и Норвегия имеют возможность разрабатывать природные ресурсы в данном регионе и претендовать на расширение границ континентального шельфа. Исландия, Швеция и Финляндия, наоборот, имеют ограниченный потенциал в Арктике, так как они не имеют прямого выхода к Северному Ледовитому океану [Арктический регион: Проблемы международного сотрудничества, 2013]. Наличие в регионе таких крупных игроков, как Россия, США и Канада, обуславливает стремление стран Северной Европы к сотрудничеству. Для проведения своей арктической политики данная группа стран создала Совет министров северных стран, Северный Совет, Северный инвестиционный банк и т. д. [Конышев, Сергунин, 2011] Тем не менее страны Северной Европы придают особое значение Арктическому Совету. Так, во время председательства Норвегии, Дании и Швеции в Совете в 2006-2013 гг. страны договорились о формировании единой «повестки дня» и координации своих действий. Однако интересы и возможности стран Северной Европы в Арктике различны, поэтому для понимания политики данной группы стран важно рассмотреть их арктические стратегии, в которых они регламентируют свою деятельность в регионе.

Стоит отметить, что Арктика представляет особый интерес для исследователей, так как в данном регионе имеется целый комплекс проблем, подлежащих изучению. Так, конфликтный потенциал Арктики в своей работе рассматривают исследователи Финского института международных отношений Й. Капюла и Х. Миккола [Käpylä, Mikkola, 2013]. Эти же авторы изучали возрастающий интерес к арктическому региону таких стран, как Россия, США, Китай и ЕC [Käpylä, Mikkola, 2013]. Деятельности Китая в арктическом регионе и, в частности, сотрудничеству данной страны с Исландией в Арктике, посвящена работа Н.А. Николаева [Николаев, 2016.] Одной из самых актуальных тем для Арктики является защита окружающей среды. Данную проблему в своей работе рассматривает старший сотрудник Института мировой политики Э. Дингман [Dingman, 2011].

Значительное внимание исследователи уделяют политике Европейского Союза в Арктике. Это можно связать с активизацией деятельности данного интеграционного блока в регионе. Политику ЕС в Арктике в своих работах рассматривают старший научный сотрудник и член группы руководителей Арктического института А. Распотник [Raspotnik, 2018] и кандидат экономических наук, ведущий научный сотрудник отдела экономических исследований Института Европы РАН Н.В. Говорова [Говорова, 2016]. Исследователи также уделяют достаточное внимание в своих работах анализу законодательных документов государств по отношению к арктическому региону. Так, например, В.Г. Александров и Н.И. Диденко в своей работе рассматривают законодательные акты циркумполярных государств по отношению к Арктике [Александров, Диденко, 2014].

В данной работе с помощью контент-анализа будут проанализированы доктринальные документы Дании, Норвегии, Исландии, Швеции и Финляндии. Благодаря выявлению частотности повторения некоторых семантических ядер в тексте документов можно будет наглядно представить ключевые направления политики этих государств в регионе. В таблице представлены семантические ядра, которые были выбраны для осуществления контент-анализа (см. таблицу 1). Выбор обусловлен тем, что в Арктике существуют некоторые общие интересы и угрозы, которые могут быть отражены в документах.

Последняя на данный момент арктическая стратегия Норвегии была принята в 2017 г. и получила название «Арктическая стратегия Норвегии - между геополитикой и социальным развитием». В данном документе было закреплено пять ключевых направлений, которые ранее были отмечены в предыдущих арктических документах. К данным направлениям относятся международное сотрудничество, развитие бизнеса, развитие знаний, инфраструктура, защита окружающей среды и обеспечение готовности к чрезвычайным ситуациям. 
Семантические ядра для проведения контент-анализа арктических стратегий стран Северной Европы

Keywords conduct content analysis of the Nordic states' arctic strategies

\begin{tabular}{|l|l|}
\hline \multicolumn{1}{|c|}{ Семантические ядра на русском языке } & \multicolumn{1}{c|}{ Семантические ядра на английском языке } \\
\hline Безопасность & $\begin{array}{l}\text { Security, security interests/needs/purposes/matters/ is- } \\
\text { sues/policy }\end{array}$ \\
\hline Национальные интересы & National/strategic/sovereign/U.S/Canadian interests \\
\hline Международное сотрудничество & International/multilateral cooperation, cooperation \\
\hline Изменение климата & Climate/environmental change \\
\hline Коренные народы & $\begin{array}{l}\text { Indigenous/Arctic/Aboriginal peoples, people of the } \\
\text { North }\end{array}$ \\
\hline Природные ресурсы & $\begin{array}{l}\text { Natural/biological resources, energy/gas/mineral } \\
\text { resources, resources }\end{array}$ \\
\hline Арктический Совет & Arctic Council \\
\hline Северный морской путь & The Northeast Passage, NEP, Northern Sea route \\
\hline Северо-западный проход & Northwest Passage \\
\hline
\end{tabular}

Для того чтобы проследить эволюцию приоритетов арктической политики Норвегии, был проведен контент-анализ стратегий данной страны по выделенным ранее семантическим ядрам (см. таблицу 2).

Таблица 2

Table 2

Результаты контент-анализа арктических стратегий Норвегии

Results of content analysis of arctic strategies of Norway

\begin{tabular}{|l|c|c|c|}
\hline \multicolumn{1}{|c|}{ Приоритет } & $\begin{array}{c}\text { Стратегия } \\
\text { правительства } \\
\text { Норвегии } \\
\text { в северных регионах } \\
(2006 \text { г.) }\end{array}$ & $\begin{array}{c}\text { Новые } \\
\text { структурне } \\
\text { элементы на } \\
\text { Севере } \\
(2009 \text { г.) }\end{array}$ & $\begin{array}{c}\text { Арктическая стратегия } \\
\text { Норвегии - между } \\
\text { геополитикой и } \\
\text { социальным развитием } \\
(2017 \text { г.) }\end{array}$ \\
\hline Безопасность & 7 & 10 & 10 \\
\hline Национальные интересы & 5 & 4 & 1 \\
\hline Международное сотрудничество & 52 & 28 & 28 \\
\hline Изменение климата & 32 & 50 & 3 \\
\hline Коренные народы & 34 & 35 & 20 \\
\hline Природные ресурсы/ ресурсы & 78 & 66 & 18 \\
\hline Арктический Совет & 10 & 11 & 1 \\
\hline Северный морской путь & 1 & 2 & - \\
\hline Северо-западный проход & - & - & \\
\hline
\end{tabular}

Посмотрев на результаты контент-анализа арктических стратегий Норвегии, можно проследить следующие тенденции. Во-первых, ключевыми направлениями, упоминающимися в данных документах, являются международное сотрудничество, изменение климата, коренные народы и природные ресурсы. Во-вторых, можно отметить, что в первых двух стратегиях 2006 и 2009 гг. семантические ядра «природные ресурсы» и «ресурсы» упоминаются чаще всего. Однако в стратегии 2017 г. данные ключевые слова по частотности употребления опустились на второе место. В новой стратегии Норвегии первое место по частотности занимает семантическое ядро «международное сотрудничество». Учитывая то, что в данном документе тема международного сотрудничества рассматривается более подробно, такое семантическое ядро, как «Арктический Совет» также используется более часто, чем в предыдущих документах. Говоря о сотрудничестве на международном уровне, стоит отметить, что особое 
внимание уделяется двустороннему сотрудничеству с Россией, которая является одним из ближайших северных соседей Норвегии. Кроме того, в стратегии 2017 г. выделяют важность сотрудничества с Европейским Союзом в Арктике. Данное направление взаимодействия представляется одним из наиболее актуальных на фоне того, что ЕС в 2016 г. опубликовал собственную арктическую стратегию. Тот факт, что тема международного сотрудничества вышла на первое место по частотности употребления в стратегии 2017 г., можно объяснить тем, что в данном документе большее внимание стали уделять именно внешнеполитическому направлению арктической политики Норвегии. Это можно увидеть и в самом названии документа, где присутствует слово «геополитика», и в оглавлении, где международное сотрудничество выделено в отдельный раздел и поставлено на первое место.

Таким образом, проанализировав три арктических стратегии Норвегии, можно отметить, что чаще всего употреблялись семантические ядра, связанные с природными ресурсами, изменением климата и коренными народами. Интерес к этим направлениям обусловлен тем, что обширная часть сухопутной территории Норвегии находится в Арктике. Также в арктическом регионе Норвегии проживает большее количество людей, чем в других циркумполярных государствах. Важность природных ресурсов для Норвегии определена тем, что ключевую роль в норвежской экономике играют газодобывающая и нефтеперерабатывающая промышленность. Тот факт, что в наиболее актуальной на данный момент стратегии Норвегии 2017 г. на первом месте по частотности находится «международное сотрудничество», можно связать с тем, что к Арктике растет число акторов, проявляющих интерес к данному региону, что открывает для Норвегии как новые возможности, так и новые вызовы.

Еще одним циркумполярным государством в Северной Европе является Дания, которая получила данный статус благодаря тому, что в ее арктический регион входят Гренландия и Фарерские острова [Аллаяров, 2017]. Следовательно, датская арктическая стратегия была одобрена по согласованию с органами управления Гренландии и Фарерских островов. Дания опубликовала свою арктическую стратегию в 2011 г. и стала одним из последних циркумполярных государств, которые обнародовали собственный документ по арктической политике.

В данном документе были выделены основные направления арктической политики Дании. К ним относятся обеспечение мирной, защищенной и безопасной Арктики, достижение самообеспеченного роста и развития, содействие развитию при бережном отношении к климату, окружающей среде и природе Арктики, тесное международное сотрудничество с иностранными партнерами.

Для того чтобы определить, на каком направлении арктической политики был сделан особый акцент, был проведен контент-анализ по выделенным ранее семантическим ядрам (см. таблицу 3).

Таблица 3

Table 3

Результаты контент-анализа арктических стратегий Дании

Results of content analysis of arctic strategies of Denmark

\begin{tabular}{|l|c|}
\hline \multicolumn{1}{|c|}{ Приоритеты } & $\begin{array}{c}\text { Стратегия Королевства Дания в отношении Арктики } \\
\text { на 2011-2020 гг. }\end{array}$ \\
\hline Безопасность & 7 \\
\hline Национальные интересы & 9 \\
\hline $\begin{array}{l}\text { Международное сотрудниче- } \\
\text { ство }\end{array}$ & 33 \\
\hline Изменение климата & 51 \\
\hline Коренные народы & 54 \\
\hline Природные ресурсы & 76 \\
\hline Арктический Совет & 40 \\
\hline Северный морской путь & 7 \\
\hline Северо-западный проход & 6 \\
\hline
\end{tabular}


По результатам проведенного анализа арктического документа Королевства Дания первое место по частотности занимают семантические ядра, относящиеся к природным ресурсам. Такое внимание к данной теме можно объяснить тем, что в Гренландии находится значительное количество природных ресурсов, включая запасы углеводорода, природного газа и редкоземельных металлов [Плевако, 2019]. На втором месте находятся семантические ядра, связанные с коренными народами Севера. На третьем месте по частотности употребления разместились ключевые слова, связанные с изменением климата. Важность данного направления обусловлена тем, что Дания активно участвует в экологическом движении и в ее политике присутствует приверженность к охране окружающей среды [Антюшина, 2014].

Также стоит отметить, что в датской арктической стратегии уделяют внимание как Северному морскому пути, так и Северо-западному проходу. Такое внимание к морским маршрутам в Арктике определено географическим положением Гренландии, которая находится между двумя данными путями и является опорным пунктом для доступа в Арктику.

Кроме того, в стратегии важным направлением является международное сотрудничество, которое играет для Дании важную роль в связи с тем, что Королевство не располагает мощными экономическими и военно-стратегическими ресурсами. Следовательно, для Дании важно многостороннее сотрудничество для продвижения своих интересов в регионе [Антюшина, 2014].

Таким образом, для арктической стратегии Королевства Дания характерны те же направления политики, что и для других циркумполярных государств. Однако особое внимание уделяется Северному морскому пути и Северо-западному проходу.

Арктическая политика Исландии сформировалась в виде официального документа в 2011 г., тогда была опубликована Парламентская резолюция по арктической политике Исландии (см. таблицу 4).

Таблица 4

Table 4

Результаты контент-анализа арктических стратегий Исландии

Results of content analysis of arctic strategies of Iceland

\begin{tabular}{|l|c|}
\hline \multicolumn{1}{|c|}{ Приоритет } & Парламентская резолюция по арктической политике (2011) \\
\hline Безопасность & 9 \\
\hline Национальные интересы & 10 \\
\hline Международное сотрудничество & 30 \\
\hline Изменение климата & 10 \\
\hline Коренные народы & 13 \\
\hline Природные ресурсы & 13 \\
\hline Арктический Совет & 20 \\
\hline Северный морской путь & 0 \\
\hline Северо-Западный проход & 2 \\
\hline
\end{tabular}

Исходя из данных таблицы, можно сделать вывод, что международному сотрудничеству в Арктике Исландия уделяет одно из центральных мест в Резолюции. Основной площадкой для выстраивания международного сотрудничества по вопросам Арктики назван Арктический Совет. Однако помимо него упоминаются оборонное сотрудничество с США, сотрудничество с Норвегией, Данией и Канадой по вопросам региональной безопасности, отношения с Европейским союзом посредством участия в «Северном измерении» (форум сотрудничества, включающий Россию, ЕС, Исландию и Норвегию), а также сотрудничество с Россией через Совет Баренцева/Евроарктического региона.

«Арктический Совет» - второй по частоте упоминания в Резолюции. Исландия очень серьезно подходит к роли этой организации в развитии арктического региона и позиционирует себя как неотъемлемую ее часть, что и подтверждает частотность использования этого семантического ядра. В документе Арктический Совет называют «главным институциональным форумом по проблемам Арктики» и звучит критика в адрес Соединенных Штатов, Канады, России, Норвегии и Дании за попытку создать консультативный форум по вопросам Арк- 
тики без участия Исландии, Финляндии и Швеции, который, в свою очередь, может подорвать авторитет Арктического совета.

Особый акцент в Резолюции Исландия делает на роли коренных народов, проживающих в Арктике. Она словно противопоставляет себя остальным арктическим государствам, заявляя, что «влиятельные страны склонны игнорировать вопросы, касающиеся коренных народов». В резолюции сказано, что такой подход должен быть преодолен под эгидой Арктического совета и через другие международные платформы, на которых решаются вопросы коренных народов Арктики.

Наравне с семантическим ядром «коренные народы» используется ядро «ресурсы». Исландия призывает придерживаться правовых норм в отношении доступа к нефтяным, газовым и другим природным ресурсам, установленным Конвенцией ООН по морскому праву. Отдельно выделена проблема использования ресурсов в контексте ответственного обращения с арктической экосистемой. Исландия в качестве одного из ключевых направлений своей политики провозглашает использование всех имеющихся средств для предотвращения антропогенного изменения климата и его последствий в целях повышения благосостояния жителей Арктики. Исландия полностью сосредоточит свои усилия на обеспечении того, чтобы активизация экономической деятельности в Арктическом регионе способствовала устойчивости арктической экосистемы. Это также подтверждается количеством упоминаний словосочетания «изменение климата».

Примерно одинаковое количество раз в резолюции встречаются семантические ядра «безопасность» и «национальные интересы». Помимо общих фраз о необходимости укрепления общей безопасности в Арктическом регионе и предотвращения его милитаризации в резолюции заявляется о намерении Исландии заключать двусторонние соглашения по вопросам безопасности с отдельными арктическими странами, подобно тем, которые она заключила с Данией, Норвегией и Канадой.

Из двух транспортных морских коридоров в Арктике в документе упомянут только Северно-Западный проход и исключительно в контексте неразрешенных проблем Арктики как предмет спора между Канадой и США.

Подводя итог анализа Парламентской резолюции по арктической политике Исландии, можно привести цитату из самой резолюции: «Правовое положение Исландии на севере нуждается в дальнейшем укреплении с целью поставить ее в равные условия с другими прибрежными государствами региона». Исландия как самое маленькое арктическое государство борется за свое место в формировании повестки дня в арктическом регионе и настаивает на равном участии всех членов Арктического Совета в разрешении споров и проблем региона.

В Финляндии также были разработаны арктические стратегии, определяющие основные направления внешней политики страны в данном регионе. Первая стратегия была опубликована в 2010 г. и получила название «Стратегия Финляндии для арктического региона». В данном документе выделены следующие разделы: хрупкая природа Арктики, экономическая деятельность и передовые технологии, транспорт и инфраструктура, коренные народы, инструменты ведения арктической политики на глобальном, региональном уровне и на уровне двустороннего взаимодействия - ЕС и арктический регион. В 2013 г. была опубликована новая арктическая стратегия «Стратегия Финляндии для арктического региона». В данном документе отражены практически те же направления деятельности в регионе, что и в предыдущем документе, однако они выражены в тексте в другой форме и расположены в другом порядке. Так, первым разделом в новом документе является видение арктической Финляндии, что включает в себя обзор деятельности Финляндии в сфере разработки новой стратегии, а также деятельность других циркумполярных стран в этой области. Далее говорится о финском населении в арктическом регионе, образовании и исследованиях, коммерческой деятельности в Арктике, окружающей среде и стабильности. Последний раздел документа посвящен международному сотрудничеству в регионе. Для того чтобы более наглядно представить наиболее актуальные направления арктической политики Финляндии, был проведен контент-анализ по определенным семантическим ядрам (см. таблицу 5). 
Результаты контент-анализа арктических стратегий Финляндии

Results of content analysis of arctic strategies of Finland

\begin{tabular}{|l|c|}
\hline \multicolumn{1}{|c|}{ Приоритеты } & Стратегия Финляндии для арктического региона (2013 г.) \\
\hline Безопасность & 55 \\
\hline Национальные интересы & 11 \\
\hline Международное сотрудничество & 184 \\
\hline Изменение климата & 36 \\
\hline Коренные народы & 26 \\
\hline Природные ресурсы & 56 \\
\hline Арктический Совет & 49 \\
\hline Северный морской путь & 9 \\
\hline Северо-западный проход & 1 \\
\hline
\end{tabular}

По результатам контент-анализа можно увидеть, что чаще всего в тексте арктической стратегии Финляндии 2013 г. повторяются семантические ядра «международное сотрудничество» и «сотрудничество». Это можно связать с тем, что Финляндия активно проявляет себя как координатор сотрудничества между разными государствами. В качестве примера можно упомянуть Северное измерение политики ЕС и так называемую «финскую инициативу», то есть работу над «Стратегией защиты окружающей среды в Арктике», которая способствовала появлению «Арктического Совета» [Антюшина, 2014]. Следовательно, ключевое словосочетание «Арктический Совет» также упоминается в тексте довольно часто.

Вторым по частоте упоминания являются семантические ядра «природные ресурсы» и «ресурсы». Важность разработки и использования природных ресурсов в Арктике обусловлена тем, что Финляндия зависит от поставок энергоресурсов, в частности, из России. Далее следует ключевое слово «безопасность». Финляндия как в стратегии 2010 г., так и в документе 2013 г. придает особое значение сохранению стабильности и обеспечению безопасности в регионе.

Таким образом, арктическая стратегия Финляндии отражает основные важные направления политики в регионе, делая особый акцент на международное сотрудничество.

Швеция - одна из стран-членов Арктического Совета, не имеющая прямого выхода к Северному Ледовитому океану [Антюшина, 2012]. Однако географическое положение обуславливает активность ее арктической политики. Арктическая стратегия Швеции была принята в 2011 г., а ее официальное название - «Стратегия Швеции в Арктическом регионе» (см. таблицу 6).

Таблица 6

Table 6

Результаты контент-анализа арктических стратегий Швеции

Results of content analysis of arctic strategies of Sweden

\begin{tabular}{|l|c|}
\hline \multicolumn{1}{|c|}{ Приоритет } & Стратегия Швеции в Арктическом регионе (2011) \\
\hline Безопасность & 11 \\
\hline Национальные интересы & 9 \\
\hline Международное сотрудничество & 83 \\
\hline Изменение климата & 35 \\
\hline Коренные народы & 37 \\
\hline Природные ресурсы & 15 \\
\hline Арктический Совет & 52 \\
\hline Северный морской путь & 4 \\
\hline Северо-Западный проход & 1 \\
\hline
\end{tabular}


Рекордсменами по частоте упоминания в документе являются семантические ядра «международное сотрудничество» и «Арктический Совет». Международное сотрудничество в Арктике, в соответствии со стратегией Швеции, должно содействовать, во-первых, обеспечению низкой политической напряженности и конфликтности в этом регионе, и во-вторых, способствовать укреплению позиций Швеции в регионе. Стратегические направления международной кооперации указаны в стратегии в следующем порядке: Арктический Совет, Европейский Союз, Северный Совет, Совет Баренцева/Евроарктического региона, ООН (Конвенция ООН по морскому праву, Международная морская организация, Комиссия по границам континентального шельфа, Всеобщая декларация прав человека, рамочная Конвенция Организации Объединенных Наций об изменении климата, Конвенция ООН о биоразнообразии и Декларация ООН о правах коренных народов), 5 арктических стран (РФ, США, Канада, Дания, Норвегия), Союз Саамов (Sámi Parliamentary Council (SPC)).

Швеция призывает активизировать работу Арктического Совета, чтобы у стран «арктической пятерки» (РФ, США, Канада, Дания, Норвегия) не было необходимости продвигать свои интересы без учета позиций Швеции, Финляндии и Исландии. В отличие от Исландии, формат «пятерки» не подвергается острой критике, Швеция выступает с прагматичным предложением, обосновывая его повышением эффективности сотрудничества в рамках данной организации.

Ключевыми направлениями своей деятельности в Арктике Швеция провозгласила борьбу с изменением климата и защиту прав коренных народов. Это подтверждается количеством упоминания соответствующих семантических ядер в Стратегии. Особое внимание в контексте работы с Саамским союзом в сотрудничестве с Россией, Финляндией и Норвегией должно уделяться вопросам, касающимся молодежи, научных исследований, саамскоязычной инфраструктуры и развития языков.

В Стратегии сказано, что изменение климата и социально-экономическое благосостояние коренных народов связаны напрямую, т. к. их традиционный образ жизни предполагает занятие оленеводством, охотой, выловом рыбы и торговлей другими биологическими ресурсами. Изменение климата означает, что многие традиционные обычаи и обеспечение средств к существованию становится труднее поддерживать. Например, Шведской Комиссией по климату и уязвимости (2007 г.) было установлено, что оленеводство будет значительно затронуто изменением климата. Проблеме социально-экономического развития коренных народов в условиях изменения климата посвящен еще один документ, упомянутый в Стратегии - доклад «Швеция перед лицом изменения климата» (2007 г.), в котором говорится о необходимости адаптации саамской культуры к экологическим изменениям.

Семантическое ядро «природные ресурсы» используется в тексте документа значительно реже, чем все предыдущие, и используется в контексте содействия рациональному использованию ресурсов Арктики. Таким образом, Швеция в очередной раз подчеркнула экологическую направленность своей экономической деятельности в Арктике.

По аналогии с Исландией термины «безопасность» и «национальные интересы» встречаются в Стратегии Швеции примерно одинаковое количество раз. Согласно Стратегии, безопасность Швеции неразрывно связана с безопасностью других стран Северной Европы. В этом контексте упоминается Декларация стран Северной Европы, которая создает пространство для координации политических приоритетов подписавших ее стран. Стратегия была принята в 2011 г., и в ней еще возлагается надежда на вступление Исландии в ЕС, что усилило бы значимость арктического региона для Евросоюза в целом, но в 2013 г. переговоры о вступлении Исландии в ЕС были заморожены.

Подчеркивается, что нынешние вызовы политики безопасности в Арктике не носят исключительно военный характер. Все большее значение приобретает необходимость разработки стратегий арктической политики в условиях изменяющегося климата, что снова подтверждает приоритетность данного направления в арктической политике Швеции.

Национальные интересы Швеции разделены не только по отраслям (энергоресурсы, минеральные и биоресурсы и т. д.), но и по географическому принципу. Швеция имеет значи- 
тельные интересы промышленной политики в Баренцевом регионе, который богат рудой, минералами, лесными и рыбными ресурсами. В остальных частях Арктики экономические интересы Швеции включают в себя нефтегазовые ресурсы, полезные ископаемые, лес, устойчивую транспортную систему и инфраструктуру, которая требует добычи полезных ископаемых, безопасное и экологичное судоходство, развитие туризма, оленеводство и др.

Северный морской путь и Северо-Западный проход не рассматриваются как аспекты политической борьбы в Арктике, а только в контексте сокращения в регионе ледового покрова и усиления транспортных возможностей двух морских коридоров. Также СМП упоминается как один из фундаментальных интересов России в Арктике при обзоре ее национальной арктической стратегии и в разделе исторического экскурса.

Подводя итог, нужно отметить, что общим для всех рассмотренных стран стало то, что наиболее значимым направлением арктической политики является международное сотрудничество. Данное семантическое ядро в рассмотренных стратегиях - одно из наиболее популярных. В качестве платформы для международного сотрудничества у некоторых из стран Северной Европы (Дания, Исландия, Швеция) в первую очередь заявлен Арктический Совет. Это говорит о значимости данной организации в выстраивании диалога между странами вокруг Арктики. Более того, Арктический Совет страны Северной Европы считают «главным институциональным форумом по проблемам Арктики», а попытки создать другие площадки рассматривают как попытки подорвать его авторитет. Доступ к природным ресурсам - второй по частоте упоминания в арктических стратегиях приоритет, что в очередной раз подтверждает значимость этого региона как ресурсной базы. Проблема извлечения ценных ресурсов неразрывно связана с проблемами устойчивости экосистемы и жизни коренных народов Арктики. Данные семантические ядра упоминаются также довольно часто в текстах арктических стратегий рассмотренных стран.

Только Финляндия делает особый акцент в своем документе на обеспечение безопасности в Арктике. В целом можно сказать, что семантические ядра «безопасность» и «национальные интересы» во всех рассмотренных доктринах встречаются значительно реже, чем все перечисленные выше.

В отношении транспортных путей об однозначности речи не идет. Две рассмотренные в работе страны упоминают в текстах своих стратегий только Северо-Западный морской проход - Дания, Исландия. Норвегия, наоборот, во всех трех своих документах, посвященных Арктике, упоминает только Северный морской путь. Две оставшиеся страны - Финляндия и Швеция - чаще используют семантическое ядро «Северный морской путь», однако упоминание Северо-Западного прохода тоже в тексте присутствует. Характерно, что авторы не нашли подтверждений того, что два морских пути рассматриваются странами Северной Европы как предметы политического спора в Арктике.

\section{Список литературы}

1. Александров В.Г., Диденко Н.И. 2014. Анализ законодательных актов по Арктике и северной территории основных арктических государств. Стратегические приоритеты развития российской Арктики: 323-336.

2. Аллаяров Р.А.У. 2017. Стратегические интересы Дании в Арктике. Гренландия - главный фактор сохранения Арктического статуса. Проблемы и перспективы. Скиф, 15: 198-202.

3. Антюшина Н.M. 2012. Арктический вызов для национальной и международной политики. М., Ин-т Европы РАН, 136.

4. Антюшина Н.M. 2014. Арктика: новый формат международного сотрудничества. М., Ин-т Европы РАН, 138.

5. Арктический регион: Проблемы международного сотрудничества: Хрестоматия в 3 томах. 2013. М., Аспект Пресс, 360.

6. Говорова Н.В. 2016. Комплексная Арктическая политика ЕС. Аналитическая записка № 13 (№ 43). URL: http://www.instituteofeurope.ru/images/uploads/analitika/an43.pdf (дата обращения: 07.12.2019). 
7. Конышев В.Н., Сергунин А.А. 2011. Арктика в международной политике: сотрудничество или соперничество? М., РИСИ, 199.

8. Николаев Н.А. 2016. Сотрудничество Китая и Исландии в Арктике. Арктика XXI век. Гуманитарные науки, 2(8): 57-66.

9. Плевако Н.С. 2019. Гренландия в планах Трампа: возрождение «Дипломатии доллаpa»? Научно-аналитический вестник Института Европы PAH. 5: 60-65. URL: https://cyberleninka.ru/article/n/grenlandiya-v-planah-trampa-vozrozhdenie-diplomatii-dollara (дата обращения: 08.12.2019).

10. A Parliamentary Resolution on Iceland's Arctic Policy. 2011. URL: https://www.government.is/media/utanrikisraduneyti-media/media/nordurlandaskrifstofa/A-

Parliamentary-Resolution-on-ICE-Arctic-Policy-approved-by-Althingi.pdf (accessed: 13.12.2019).

11. Andreas Raspotnik. 2018. The European Union and the Geopolitics of the Arctic. Cheltenham: Edward Elgar Publishing, 240. URL: https://www.cambridge.org/core/journals/polarrecord/article/european-union-and-the-geopolitics-of-the-arctic-andreas-raspotnik-2018-cheltenhamedward-elgar-publishing-240-p-hardcover-gbp-7200/7B37D616154E19A5AC8285CED51E7C6F （accessed: 20.12.2019).

12. Dingman, Erica M. 2011. Arctic Sustainability: The Predicament of Energy and Environmental Security. Connections, 11 (1): 1-10. URL: www.jstor.org/stable/26326260. (accessed: 07.12.2019).
13. Finland's
Strategy
for the
Arctic
Region.
URL: http://library.arcticportal.org/1262/1/Finland_Arctic_Strategy.pdf (accessed: 12.12.2019).

14. Käpylä, J., Mikkola, H. 2013. Arctic Conflict Potential: Towards an extra-Arctic perspective. FIIA Briefing paper 138, CIAO. URL: http://www.ciaonet.org/record/29275?search=1 (accessed: 23.04.2019).

15. Käpylä, J., Mikkola, H. 2013. The Global Arctic: The Growing Arctic Interests of Russia, China, the United States and the European Union. FIIA Briefing paper 133, CIAO. URL: http://www.ciaonet.org/record/28992?search=1 (accessed: 23.12.2019).

16. National Strategy for the Arctic region. 2013. URL: https://obamawhitehouse.archives.gov/ sites/default/files/docs/nat_arctic_strategy.pdf (accessed: 29.11.2019).

17. New Building Blocks in the North. URL: https://www.regjeringen.no/globalassets/upload/ud/vedlegg/nordomradene/new_building_blocks_in_the_ north.pdf (accessed: 11.11.2019).

18. Norway's Arctic Strategy - between geopolitics and social development. URL: https://www.regjeringen.no/contentassets/fad46f0404e14b2a9b551ca7359c1000/arctic-strategy.pdf (accessed: 11.11.2019).

19. Sweden's Strategy for the Arctic region. 2011. URL: https://www.government.se/49b746/contentassets/85de9103bbbe4373b55eddd7f71608da/swedensstrategy-for-the-arctic-region (accessed: 11.12.2019).

20. The Norwegian Government's High North Strategy. URL: https://www.regjeringen.no/globalassets/upload/ud/vedlegg/strategien.pdf (accessed: 11.11.2019).

\section{References}

1. Aleksandrov V.G., Didenko N.I. 2014. Analiz zakonodatel'nyh aktov po Arktike i severnoj territorii osnovnyh arkticheskih gosudarstv [Analysis of legislation on the Arctic and the northern territory of the main Arctic states]. Strategicheskie prioritety razvitiya rossijskoj Arktiki: 323-336.

2. Allayarov R.A.U. 2017. Strategicheskie interesy Danii v Arktike. Grenlandiya - glavnyj faktor sohraneniya Arkticheskogo statusa. Problemy i perspektivy [Strategic interests of Denmark in the Arctic. Greenland is the main factor in preserving the Arctic status. Problems and prospects]. Skif, 15: 198-202.

3. Antyushina N.M. 2012. Arkticheskij vyzov dlya nacional'noj i mezhdunarodnoj politiki [Arctic Challenges in the National and International Politics]. M., In-t Evropy RAN, 136.

4. Antjushina N.M. 2014. Arktika: novyj format mezhdunarodnogo sotrudnichestva [Arctic: a New Framework of the International Cooperation]. M., In-t Evropy RAN, 138.

5. Arkticheskij region: Problemy mezhdunarodnogo sotrudnichestva: Hrestomatiya v 3 tomah [The Arctic Region: Problems of International Cooperation: Anthology in 3 volumes.]. 2013. M., Aspekt Press, 360.

6. Govorova N.V. 2016. Kompleksnaya Arkticheskaya politika ES [EU Integrated Arctic Policy]. Analiticheskaya zapiska № 13 (№ 43). http://www.instituteofeurope.ru/images/uploads/analitika/an43.pdf (data obrashcheniya: 07.12.2019). 
7. Konyshev V.N., Sergunin A.A. 2011. Arktika v mezhdunarodnoj politike: sotrudnichestvo ili sopernichestvo? [The Arctic in international politics: cooperation or rivalry?]. M., RISI, 199.

8. Nikolaev N.A. 2016. Sotrudnichestvo Kitaya i Islandii v Arktike [China and Iceland cooperation in the Arctic]. Arktika XXI vek. Gumanitarnye nauki, 2(8): 57-66.

9. Plevako N.S. 2019. Grenlandija v planah Trampa: vozrozhdenie «Diplomatii dollara»? [Greenland in Trump's plans: revival of «Dollar diplomacy»?] Nauchno-analiticheskij Vestnik Instituta Evropy RAN. 5: 60-65. URL: https://cyberleninka.ru/article/n/grenlandiya-v-planah-trampavozrozhdenie-diplomatii-dollara (accessed: 08.12.2019).

10. A Parliamentary Resolution on Iceland's Arctic Policy. 2011. URL: https://www.government.is/media/utanrikisraduneyti-media/media/nordurlandaskrifstofa/A-

Parliamentary-Resolution-on-ICE-Arctic-Policy-approved-by-Althingi.pdf (accessed: 13.12.2019).

11. Andreas Raspotnik. 2018. The European Union and the Geopolitics of the Arctic. Cheltenham: Edward Elgar Publishing, 240. URL: https://www.cambridge.org/core/journals/polarrecord/article/european-union-and-the-geopolitics-of-the-arctic-andreas-raspotnik-2018-cheltenhamedward-elgar-publishing-240-p-hardcover-gbp-7200/7B37D616154E19A5AC8285CED51E7C6F （accessed: 20.12.2019).

12. Dingman, Erica M. 2011. Arctic Sustainability: The Predicament of Energy and Environmental Security. Connections, 11 (1): 1-10. URL: www.jstor.org/stable/26326260. (accessed: 07.12.2019).

13. Finland's Strategy for the Arctic Region. URL: http://library.arcticportal.org/1262/1/Finland_Arctic_Strategy.pdf (accessed: 12.12.2019).

14. Käpylä, J., Mikkola, H. 2013. Arctic Conflict Potential: Towards an extra-Arctic perspective. FIIA Briefing paper 138, CIAO. URL: http://www.ciaonet.org/record/29275? search=1 (accessed: 23.04.2019).

15. Käpylä, J., Mikkola, H. 2013. The Global Arctic: The Growing Arctic Interests of Russia, China, the United States and the European Union. FIIA Briefing paper 133, CIAO. URL: http://www.ciaonet.org/record/28992?search=1 (accessed: 23.12.2019).

16. National Strategy for the Arctic region. 2013. URL: https://obamawhitehouse.archives.gov/sites/default/files/docs/nat_arctic_strategy.pdf (accessed: 29.11.2019).

17. New Building in the North. URL: https://www.regjeringen.no/globalassets/upload/ud/vedlegg/nordomradene/new_building_blocks_in_the_ north.pdf (accessed: 11.11.2019).

18. Norway's Arctic Strategy - between geopolitics and social development. URL: https://www.regjeringen.no/contentassets/fad46f0404e14b2a9b551ca7359c1000/arctic-strategy.pdf (accessed: 11.11.2019).

19. Sweden's Strategy for the Arctic region. 2011. URL: https://www.government.se/49b746/contentassets/85de9103bbbe4373b55eddd7f71608da/swedensstrategy-for-the-arctic-region (accessed: 11.12.2019).

20. The Norwegian Government's High North Strategy. URL: https://www.regjeringen.no/globalassets/upload/ud/vedlegg/strategien.pdf (accessed: 11.11.2019).

\section{Ссылка для цитирования статьи Link for article citation}

Бокерия С.А., Кернер Е.А., Кузнецова Д.А. 2020. Эволюция приоритетов арктической политики стран Северной Европы (на основе контент-анализа доктринальных документов). Via in tempore. История. Политология, 47 (2): 416-426. DOI 10.18413/2687-0967-2020-47-2-416-426.

Bokeriya S.A., Kerner E.A., Kuznetsova D.A. 2020. Evolution of arctic policy priorities of the nordic countries (based on content analysis of doctrines). Via in tempore. History and political science, 47 (2): 416-426 (in Russian). DOI 10.18413/2687-0967-2020-47-2-416-426. 